\title{
Purification of an ovine, androgen-dependent epididymal protein. Evidence for a strong amino acid sequence homology with serum albumin
}

\author{
C Carles 1, S Fournier-Delpech 2, B Ribadeau-Dumas ${ }^{*}$ *
}

\author{
1 INRA Bât 224, Unité Protéines, 78352 Jouy-en-Josas Cedex; \\ 2 INRA, Station de Physiologie de la Reproduction, Unité de Recherches Associée INRA-CNRS, \\ Nouzilly, 37380 Monnaie, France
}

(Received 9 December 1991; accepted 7 May 1992)

\begin{abstract}
Summary - An ovine, testosterone-dependent protein was purified from an extract of epididymides of orchidectomized-, testosterone-implanted rams by ethylene glycol precipitation, anion exchange chromatography, preparative non-denaturing PAGE at alkaline $\mathrm{pH}$ and gel filtration. The protein which had previously been named ovine prealbumin-epididymis-specific protein (OPES), migrated as a single band ahead of ovine serum albumin (OSA). A single component, with an apparent MW of $60 \mathrm{kDa}$, lower than that of OSA, was also observed in SDS-PAGE. OPES was cleaved after lysyl residues using endoproteinase Lys-C and the hydrolysate was fractionated in 2 steps by reverse-phase HPLC. Six oligopeptides were recovered and sequenced. They all displayed complete identity with regions of bovine serum albumin scattered in the two-third $\mathrm{N}$-terminal part. However, in 2 of them, there was no complete identity with homologous parts of OSA. This indicates that oPES and OSA are probably encoded by different genes.
\end{abstract}

\section{ram / epididymis / androgen-dependent protein / serum albumin}

Résumé - Purification d'une protéine ovine épididymaire, dépendant des androgènes. Mise en évidence d'une forte homologie de séquence avec la sérum-albumine. Une protéine ovine, dépendante de la testostérone, a été purifiée, à partir d'un extrait d'épididymes de béliers orchidectomisés porteurs d'implants de testostérone, par précipitation au polyéthylène glycol, chromatographie d'échange d'anions, électrophorèse préparative en gel de polyacrylamide à pH alcalin en milieu non dénaturant, et filtration sur gel. La protéine donnait une seule bande migrant en avant de la sérum albumine ovine (oSA), d'où le nom qui lui a été donné antérieurement : ovine pré-albumine épididyme spécifique (OPES). Un seul constituant, de masse moléculaire apparente $60 \mathrm{kDa}$, inférieure à celle de l'oSA, fut aussi observé en électrophorèse sur gel de polyacrylamide en présence de SDS. $L$ 'oPES fut clivée après les résidus lysyle en utilisant l'endoprotéinase $L y s-C$, et l'hydrolysat fractionné en 2 étapes par HPLC en phase inverse. Six oligopeptides ont été obtenus et séquencés. Ils présentent tous une identité complète avec des régions de la molécule de sérum-albumine bovine situées dans les 2/3 N-terminaux. Cependant, pour 2 d'entre eux, il n'y a pas identité complète avec les parties homologues de l'OSA. Ceci indique que l'OPES et l'OSA sont probablement codées par des gènes différents.

\section{bélier / épididyme / protéine dépendante des androgènes / sérum-albumine}

\footnotetext{
* Correspondence and reprints
} 


\section{INTRODUCTION}

During their transit through the epididymis, spermatozoa undergo specific physical, biochemical and morphological changes resulting in the appearance of the flagellar motility and zona pellucida receptors on the plasma membrane of the head (FournierDelpech and Thibault, 1991). These changes occur together with variations in the contents of the epididymal lumen due to the synthesis, metabolism, absorption and secretion of compounds such as steroids, carnitine, or proteins (Cooper, 1986). Androgen-dependent, epididymal secretory proteins play a role in sperm maturation (Cuasnicu et al, 1984; Fournier-Delpech et al, 1985). In the ram, one of these proteins, previously referred to as ovine prealbuminepididymis-specific protein (oPES) has been found on the plasma membrane covering the acrosomal cap of epididymal spermatozoa but not of testicular spermatozoa (Fournier-Delpech et al, 1985). This paper reports a procedure for an efficient preparation of oPES and its partial characterization from amino acid sequence data.

\section{MATERIAL AND METHODS}

\section{Animals, chemicals and material}

Animals were adult lle-de-France rams. Testosterone was from Roussel-Uclaf (Paris, France), polyethylene glycol (PEG) from Prolabo (Paris, France), Uitrogel ACA44 from IBF (VilleneuveLa-Garenne, France), DEAE-Sephacel from Pharmacia (Uppsala, Sweden), acrylamide from Tebu (Le Perray-en-Yvelines, France), endoproteinase Lys-C from Boehringer (Mannheim, Germany), bovine serum albumin (BSA) from Sigma (St Louis, USA). Reverse-phase HPLC was performed with a Millipore-Waters system (Milford, USA). The 477A-120A sequencer and its reagents were from Applied Biosystems (Foster City, USA). The Speed-Vac concentrator was from Savant (Hicksville, USA).

\section{Purification of OPES}

Epididymides were collected from 15 orchidectomized-, testosterone-implanted rams (FournierDelpech et al, 1981) and freed from most connective envelopes on ice. The following operations were performed at room temperature in the presence of sodium azide. The tissues were minced and homogenized in a $3 \mathrm{mM}$ Tris- $\mathrm{HCl}$ buffer, $\mathrm{pH} 8.8$, containing $0.2 \%$ sodium azide, referred to below as $\mathrm{TH}$ ( $3 \mathrm{ml}$ per $\mathrm{g}$ tissue). After filtration on gauze and centrifugation $(30000 \mathrm{~g}$, $10 \mathrm{~min}$ ), aliquots of the supernatant were treated with solid PEG $4000(5,10,15,20,25$ or 30 $\mathrm{g}$ added to $100 \mathrm{ml}$ ). A further centrifugation as above gave 6 supernatants (S5 to S30) which were analyzed by PAGE $(7.5 \%$ acrylamide, Tris-glycine buffer, $\mathrm{pH}$ 8.3) under nondenaturing conditions, to localize oPES after $\mathrm{ZnCl}_{2}$ (Wang et al, 1989) and Coomassie blue staining. Most oPES was in S25; it was precipitated by addition of solid PEG-6000 ( $30 \mathrm{~g}$ to 100 $\mathrm{ml})$. After centrifugation as above, precipitate $(P+30)$ was dissolved in a minimum volume of $\mathrm{TH}, 0.1 \%$ Tween 20 , and chromatographed on a DEAE-Sephacel column $(3 \times 5 \mathrm{~cm})$ equilibrated in $\mathrm{TH}$ with recording at $280 \mathrm{~nm}$. The proteins eluted in $0.33 \mathrm{M} \mathrm{NaCl}$ were concentrated and desalted by dialysis against PEG- 6000 and submitted to preparative non-denaturing PAGE after $90 \mathrm{~min}$ pre-electrophoresis, then stained as above. OPES and OSA were eluted, concentrated by dialysis against PEG as above, passed through an ACA44 column $(1 \times 90 \mathrm{~cm})$ in water. After protein determination (Lowry et al, 1951), each recovered fraction was divided in $300-\mu \mathrm{g}$ aliquots and freeze-dried. The purity of each protein was assessed by SDS-PAGE, after 2mercapto-ethanol reduction and 3 min boiling, in $15 \%$ acrylamide and silver staining (Morrissey, 1981).

\section{Preparation and sequencing of internal oligopeptides}

Direct sequencing of oPES (ca $1 \mathrm{nmol}$ ) was attempted 3 times without success. The protein (ca $1 \mathrm{mg}$ ) was digested by endoproteinase Lys$\mathrm{C}$ in $100 \mu \mathrm{l} 0.1 \mathrm{M}$ ammonium bicarbonate buffer, $\mathrm{pH}$ 8.8. The reaction was performed overnight at $37^{\circ} \mathrm{C}$ with an enzyme to substrate ratio of $1 / 100$ $(w / w)$. After Speed-Vac drying, the digest was 
dissolved in $25 \mathrm{mM}$ ammonium acetate, $\mathrm{pH} 6.7$, (solvent $A_{1}$ ) and injected on a Nucleosil C18 reverse-phase column (5- $\mu \mathrm{m}$ beads, $10-\mathrm{nm}$ pores, $250 \times 4.6 \mathrm{~mm}$; SFCC, France) equilibrated in solvent $A_{1}$ and kept at $40^{\circ} \mathrm{C}$. The elution was achieved by a linear gradient from solvent $A_{1}$ to solvent $B_{1}(20 \% 100 \mathrm{mM}$ ammonium acetate, $\mathrm{pH} 6.7 ; 80 \% \mathrm{CH}_{3} \mathrm{CN}$ ) in $60 \mathrm{~min}$ at a flow rate of $1 \mathrm{ml} / \mathrm{min}$ with absorbance recording at $214 \mathrm{~nm}$. The 6 main fractions were collected, Speed-Vac dried, dissolved in $0.1 \%$ trifluoroacetic acid (TFA) and rechromatographed as above, with elution by a linear gradient from solvent $A_{2}$ $\left(0.11 \%\right.$ TFA) to solvent $\mathrm{B}_{2}\left(80 \% \mathrm{CH}_{3} \mathrm{CN}, 0.1 \%\right.$ TFA) in $30 \mathrm{~min}$. After Speed-Vac drying, each recovered peptide was automatically sequenced.

\section{RESULTS AND DISCUSSION}

\section{OPES preparation}

OPES was shown by non-denaturing PAGE to be mainly present in fraction S25 (fig 1), which contained $45 \%$ of the soluble proteins of the initial epididymal extract. Precipitate $(P+30)$, obtained by PEG6000 treatment of $S 25$, contained $11 \%$ of

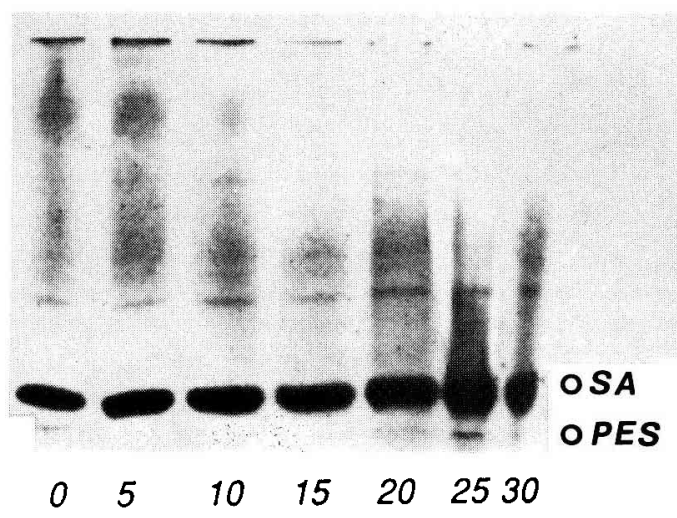

Fig 1. Non-denaturating PAGE of the soluble epididymis extract $(0)$ and its PEG precipitation supernatants 5-30. The figures refer to the PEG concentrations. the whole protein extract, mainly $O S A$ and oPES.

An atypical elution of $(P+30)$ proteins by $\mathrm{TH}$ from DEAE-Sephacel was observed: the proteins were not retained by the ion-exchanger. This agrees with other observations on atypical behaviour of proteins in gel filtration due to PEG (Arakawa, 1985). After different attempts to eliminate $P E G$, we found that the addition of Tween 20 to the dissolved $(P+30)$ allowed protein retention on the column and elution of oPES together with oSA by $0.33 \mathrm{M} \mathrm{NaCl}$, as previously observed (Fournier-Delpech et al, 1988, 1990). For further preparations, $(P+30)$ in TH, $0.1 \%$ Tween 20, was loaded on the ion-exchanger equilibrated in $\mathrm{TH}$ containing $0.20 \mathrm{M} \mathrm{NaCl}$, washed with this solution and oPES was eluted by $0.33 \mathrm{M} \mathrm{NaCl}$ in $\mathrm{TH}$ (fig 2) and purified by electrophoresis as indicated in the Methods section, together with oSA.

\section{oPES electrophoretic behaviour}

On PAGE purified oPES migrated as a single band, faster than $O S A$, in the prealbumin region (fig 2). From SDS-PAGE, it displayed, and apparent MW of ca $60 \mathrm{kDa}$, lower than that of OSA (fig 3). In both systems a single component was observed.

\section{Sequence data}

From direct sequencing it appeared that oPES was probably $\mathrm{N}$-terminally blocked since no PTH-amino acid was released on any Edman cycle. in order to generate a limited number of oligopeptides, native oPES was enzymatically digested. Indeed, most globular proteins undergo limited superficial proteolysis if they have not been previously denatured. Endoproteinase Lys$\mathrm{C}$, which cleaves peptide chains after lysyl 


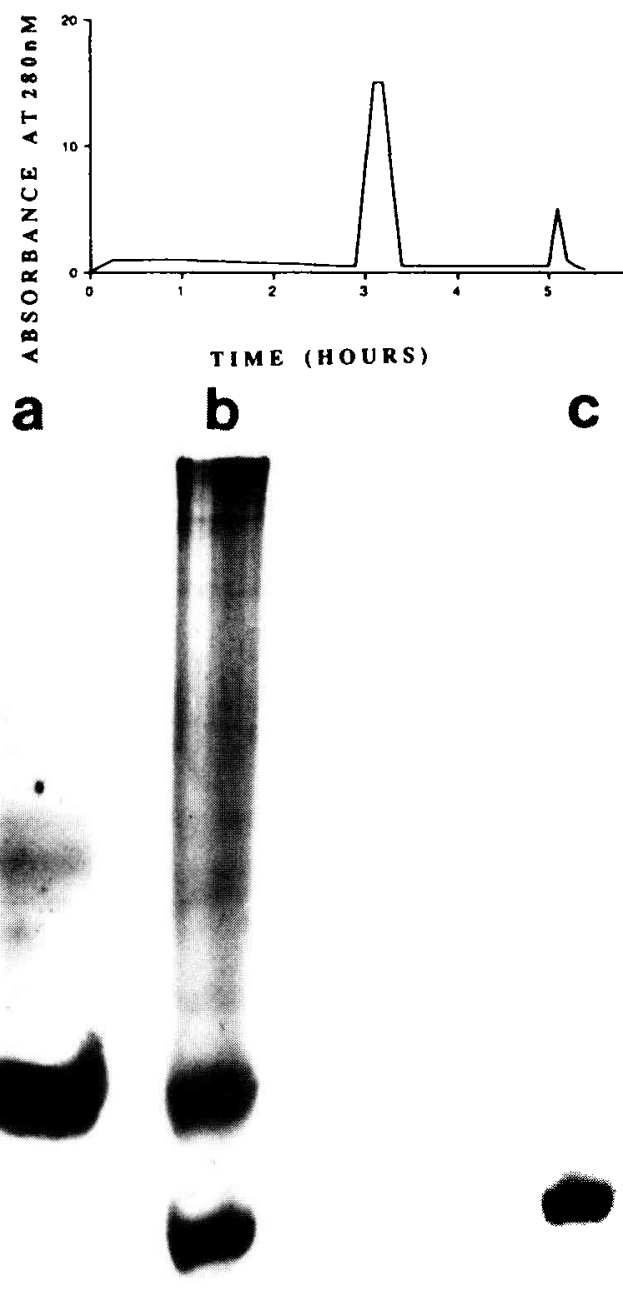

Fig 2. Purification of oPES by DEAE-Sephacel column chromatography and preparative electrophoresis. Top : Elution profile of $(P+30)$ from DEAE-Sephacel. First peak: proteins eluted by $0.2 \mathrm{M} \mathrm{NaCl}$. Second peak: proteins eluted by $0.33 \mathrm{M} \mathrm{NaCl}$. Bottom :P 280280 Nondenaturating PAGE of proteins eluted by 0.2 (a) and 0.33 (b) M NaCl.c, oPES obtained by preparative electrophoresis from the second fraction $(0.33 \mathrm{M} \mathrm{NaCl})$. The main spot in (a) is OSA.

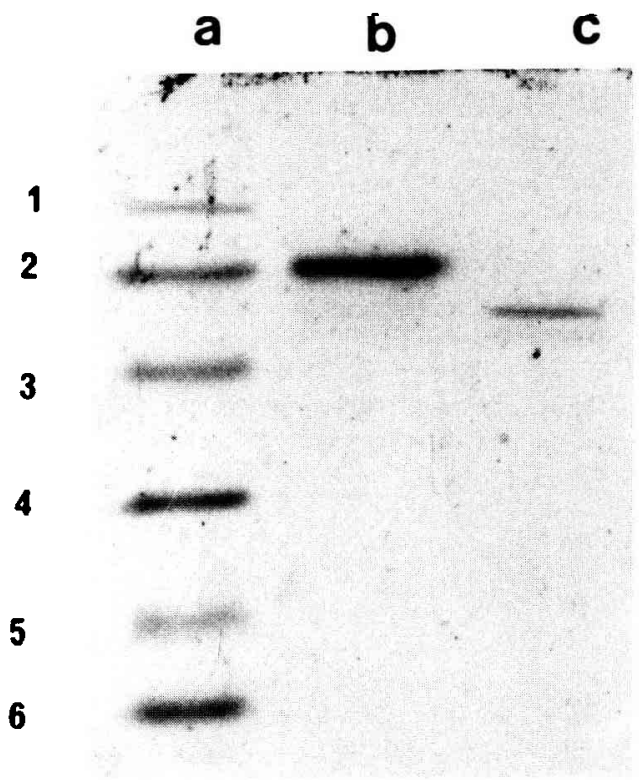

Fig 3. SDS-PAGE of electrophoretically purified OSA (b) and OPES (c). a, mw markers: 96 (1), 67 (2 and bSA), 43 (3), 30 (4), 20.1 (5) and 14.4 $\mathrm{kDa}(6)$. Silver staining.

residues, was employed. HPLC fractionation of the whole digest gave 6 main fractions, A-F (fig 4). Fraction $F$ did not contain enough material for further analysis. The 5 remaining fractions were purified by chromatography in another solvent system. Fraction $\mathrm{C}$ gave 2 pure peptides, $\mathrm{C} 1$ and $\mathrm{C}_{2}$, while the other 4 fractions gave each a single pure peptide. They were called A, B, D and E (fig 5 a, b, c, d). In figure 5 the peaks with retention times below $10 \mathrm{~min}$ correspond to the injection, while those appearing between 10-15 min are artefactual (the corresponding fractions do not contain any peptide). The 6 peptides were sequenced. A search in data banks showed that they were identical to regions of bSA amino acid sequence (Brown and Shockley, 1982) and are released in accordance with the specificity of endoproteinase Lys-C (fig 6). As usual when se- 


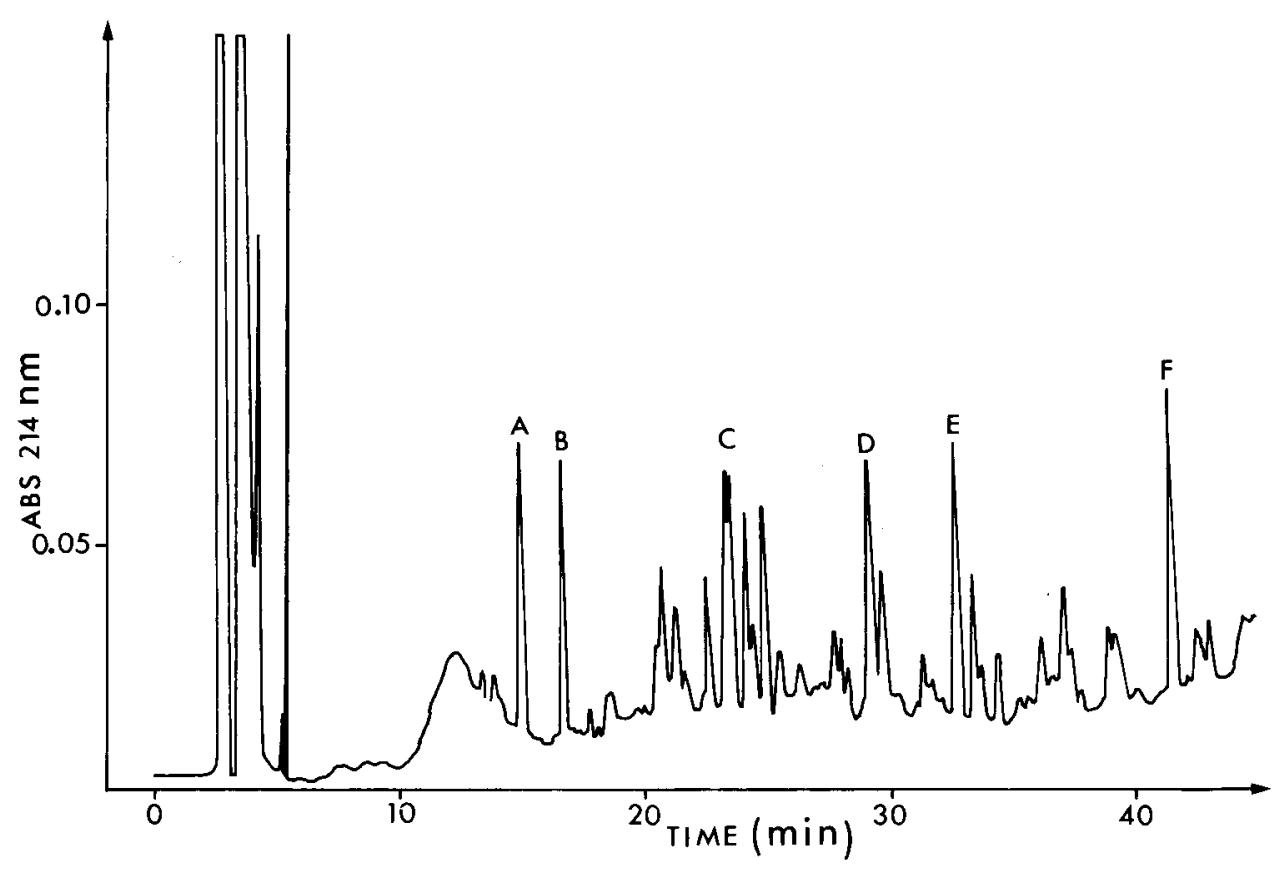

Fig 4. Reverse-phase HPLC of the endoproteinase Lys-C digest of oPES. Column: Nucleosil (SFCC, France; C18, $5-\mu \mathrm{m}$ beads, $10-\mathrm{nm}$ pores, $250 \times 4.6 \mathrm{~mm}$ ). Linear gradient from $25 \mathrm{mM}$ ammonium acetate $\mathrm{pH} 6.7$ to $85 \%$ solvent $\mathrm{B}_{1}\left(20 \% 100 \mathrm{mM}\right.$ ammonium acetate $\left.\mathrm{pH} 6.7,80 \% \mathrm{CH}_{3} \mathrm{CN}\right)$ in $60 \mathrm{~min}$. Column temperature: $40^{\circ} \mathrm{C}$. Flow rate: $1 \mathrm{ml} / \mathrm{min}$. Fractions $A, B, C, D$ and $E$ were collected, dried and rechromatographed (fig 5 ).

quencing the $C$-terminus of peptides, apart from $D$, the last (peptides $A, C 1, C 2$ and $E$ ) or last 2 (peptide $B$ ) residue(s) could not be identified. The 6 peptides are located in region $37-410$ (numbering from the initiator Met) of bSA. They were also searched for in the recently published sequence of oSA, deduced from that of its CDNA, which is $>90 \%$ identical to that of bSA (Brown et al, 1989). Indeed, peptides C1, C2, D and $E$ were found in homologous positions, each beginning after a lysine and having lysine as C-terminal amino acid. However, for peptide $A$, an His (OPES) replaced an Asn (OSA). Furthermore, the specificity of the endoproteinase Lys-C did not fit with the C-terminal GIn. For peptide B, 3 differ- ences occurred between oPES or bSA and oSA: Glu $\rightarrow$ Asp twice, Val $\rightarrow$ Thr (oPES $\rightarrow$ oSA).

We are then faced with a surprising result: in 6 small regions, oPES appears to be identical with bSA, while 2 of them are clearly different from the corresponding regions of oSA (fig 6). However, oPES differs from bSA in electrophoretic behaviour: its apparent MW in SDS-PAGE is lower than that of OSA which is the same as bSA; it migrates faster in non-denaturing PAGE. Furthermore, anti-oPES serum saturated with bSA reacts with oPES (Fournier-Delpech et al, 1988). Could it be that, in the ram, both a gene encoding $b S A$, which could be postranslationally modified (eg by 
C Carles et al
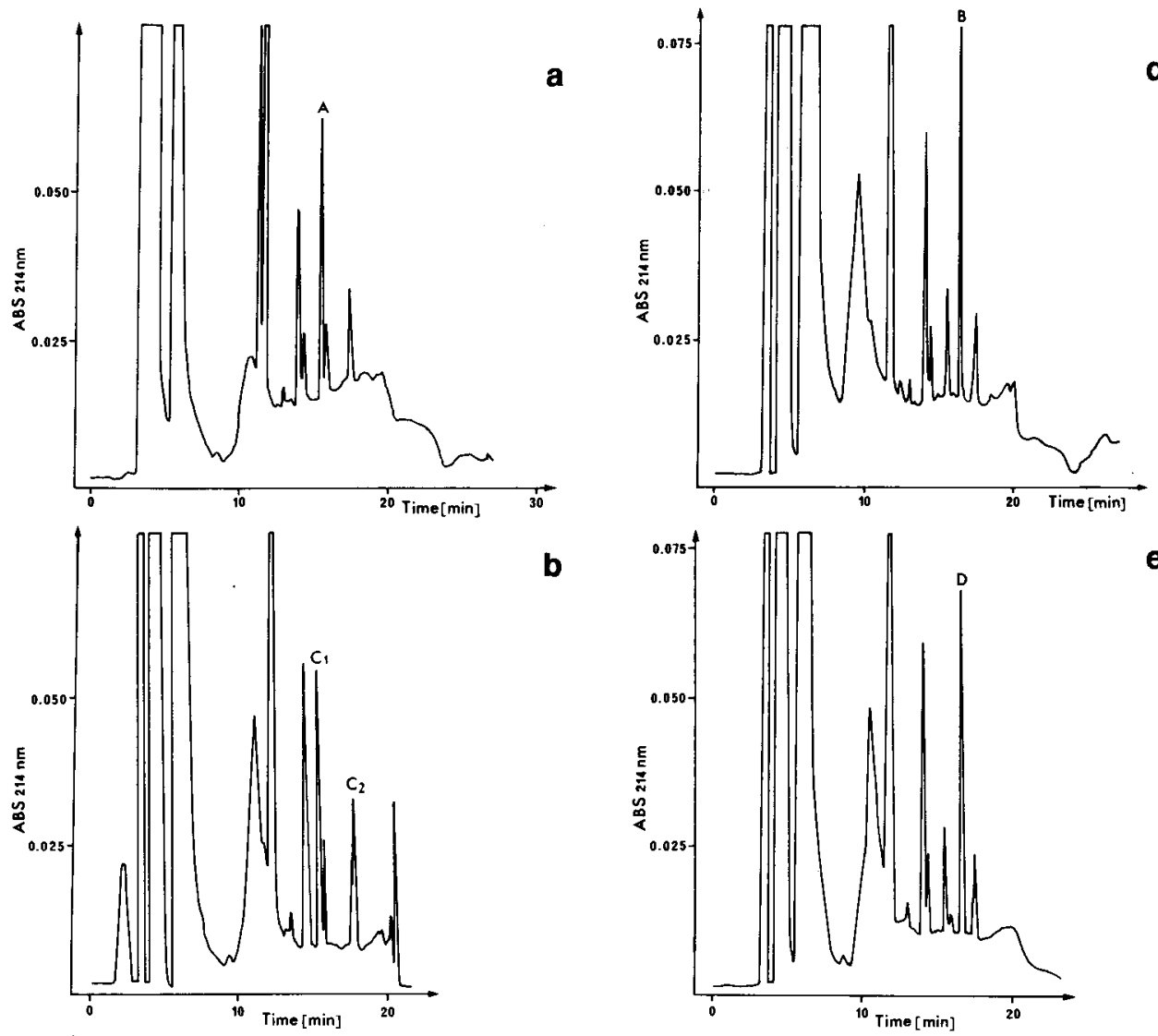

b
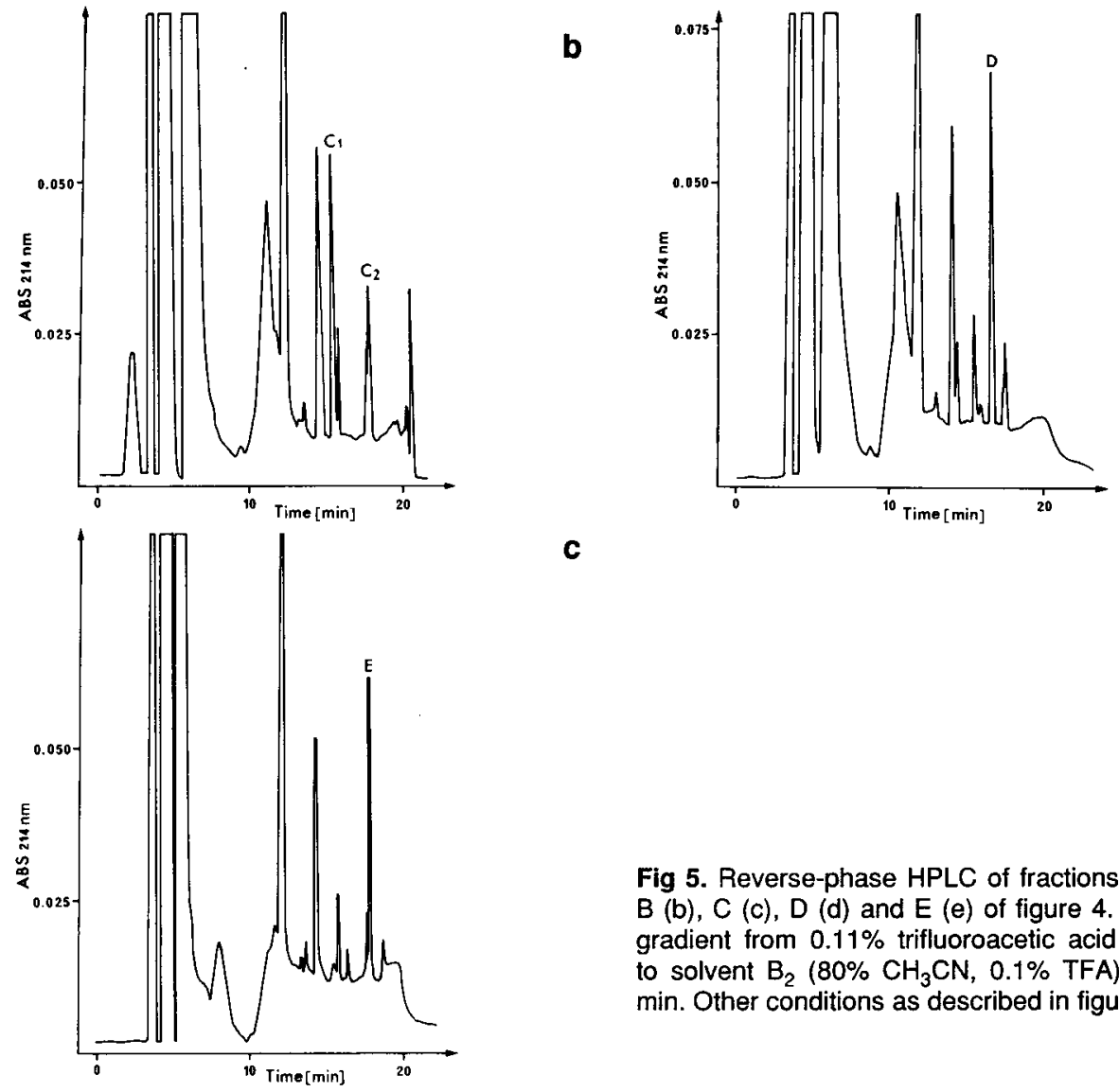

C

Fig 5. Reverse-phase HPLC of fractions A (a), $B$ (b), C (c), D (d) and $E$ (e) of figure 4. Linear gradient from $0.11 \%$ trifluoroacetic acid (TFA) to solvent $\mathrm{B}_{2}\left(80 \% \mathrm{CH}_{3} \mathrm{CN}, 0.1 \%\right.$ TFA) in 30 $\mathrm{min}$. Other conditions as described in figure 4.

proteolysis, glycosylation) to give oPES, and a gene encoding OSA be present, taking into account that these genes originate

from a common acestor? This is hard to believe since it implies that an identical evolution from a common precursor resulted 

OPES OSA

$\mathrm{bSA}$

hSA rSA
A 37

1

DLGEHE

NDLGEENEQ

KDLGEEHFK

KDLGEENEK

KDLGEQHEK
D

157<smiles>C[14CH][14CH]</smiles>

KFWGK

KFWGK

TFLKK

SELGH
C1

228<smiles>C[14CH2][14CH2][14CH2][14CH3]</smiles>

KFGERALK

KFGERALK

KFGERAFK

KFGERAFK

C2

B

$\mathbf{E}$

235

248

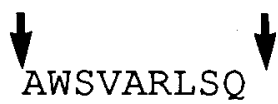

$\downarrow$

AEFVEV

401

OPES

KAWSVARLSQK

KADFTDVTK

KHLVDEPQNLIK

bSA

KAWSVARLSQK

KAEFVEVTK

KHLVDEPQNLIK

hSA

KAWAVARLSQR

KAEFAEVSK

KP LVEEPQNLIK

rSA

KAWAVARMSQR

NAEFAEITK

QP LVEEPKNLVK

Fig 6. Comparison of the 6 peptides $\left(A, B, C_{1}, C_{2}, D, E ;\right.$ fig 5) from oPES with the homologous regions of 4 known serum albumins. hSA, human; rSA, rat; OSA, ovine; bSA, bovine. For each peptide, first arrow: cleavage site in oPES; second arrow: most probable cleavage site in oPES. $H$, uncertain identification. Bold-faced: residues differing in OPES and OSA, and residues identical to those of oPES in bSA, hSA or rSA at the same positions.

in bSA in bovines and oPES in ovines. We are of the opinion that the genes encoding bSA, OSA and OPES are different and originate from a common precursor. The evolution from this precursor to OSA and oPES would have followed a different pathway and oPES is almost certainly different from bSA in parts of the molecule that have not been studied, and it is worth noting (fig 6) that several of the substitutions we observed between oPES and OSA do not exist when oPES is compared with rat or human serum albumin.

No relationship was found between oPES and "rat-PES", also called protein D$\mathrm{E}$ (Fournier-Delpech et al, 1988) whose $\mathrm{MW}$ is ca $32 \mathrm{kDa}$ and cDNA sequence is known (Brooks et al, 1986). 


\section{ACKNOWLEDGMENT}

The authors thank $Y$ Combarnous for help and advice during the course of this work.

\section{REFERENCES}

Arakawa T (1985) The mechanism of increased elution volume of proteins by polyethylene glycol. Anal Biochem 144, 267-268

Brooks DE, Means AR, Wright EJ, Singh SP, Tiver KK (1986) Molecular cloning of CDNA for androgen-dependent sperm coating glycoproteins secreted by the rat epididymis. Eur J Biochem 101, 13-18

Brown JR, Shockley P (1982) Serum albumin: structure and characterization of its ligand binding sites. In: Lipid-Protein Interactions (Jost P, Griffith $\mathrm{OH}$, eds) Wiley, NY, vol 1 , 25-68

Brown WM, Dziegiewska KM, Foreman RC, Saunders NR (1989) Nucleotide and deduced amino acid sequence of sheep serum albumin. Nucleic Acids Res 17, 10495

Cooper TG (1986) The Epididymis, Sperm Maturation and Fertilization (Cooper G, ed) Springer Verlag, Berlin

Cuasnicu PS, Piazza A, Cameo MS, Blaquier JA (1984) Antibodies against epididymal glycoproteins block fertilizing ability. $J$ Reprod Fertil 72, 467-471

Fournier-Delpech S, Thibault C (1991) Acquisition de la fécondance du spermatozoide : maturation épididymaire, glandes annexes et capacitation. In: La Reproduction Chez Les Mammifères Domestiques et L'Homme (Thi- bault $C$, Levasseur MC, eds) Ellipse, Paris, 251-272

Fournier-Delpech S, Pisselet C, Garnier DH, Dubois MP, Courot M (1981) Localisation sur la tête des spermatozoides de bélier des sites d'affinité pour la préalbumine épididymaire androgène-dépendante $64 \mathrm{kDa}$. CR Acad Sci Paris Sér III 293, 589-594

Fournier-Delpech $S$, Courot M, Dubois MP (1985) Decreased fertility and motility of spermatozoa from rats isoimmunized with a prealbumin epididymal specific protein. Int $J A n$ drol 6, 246-250

Fournier-Delpech S, Holland MK, Skudlarek MD, Rankin TL, Orgebin-Crist MC, Courot M (1988) A ram epididymal secretory protein shares common antigenic determinants with rat epididymal proteins and human seminal plasma proteins. Reprod Nutr Dév 28, 12831299

Fournier-Delpech S, Carles C, Ribadeau-Dumas B (1990) Purification of ram epididymal androgen-dependant protein "préalbumine épididymaire spécifique" (oPES). In: Protein Purification Technologies (Briand $\mathrm{Y}$, Doinel $E$, Faure A, eds) GRBP, Villebon-sur-Yvette, France, vol 4, 131-136

Lowry $\mathrm{OH}$, Rosenbough NJ, Fara AL, Randall RJ (1951) Protein measurement with Folin phenol reagent. J Biol Chem 193, 265-273

Morrissey JH (1981) Silver stain for proteins in acrylamide gels: a modified procedure with enhanced uniform sensitivity. Anal Biochem $117,307-310$

Wang D, Dzandu JK, Hussain M, Johnson RM (1989) Western blots from sodium dodecyl sulfate polyacrylamide gels stained by metal salts. Anal Biochem 180, 311-313 